\title{
Gheorghe Dima - an important personality of Romanian culture
}

\section{Dorin Mircea SIMIONESCU*}

Abstract: In the essential data of choral and vocal creation, Gheorghe Dima retains all the attributes of the romantic language in which he has formed. In his religious choirs and madrigals there is an eminently tonal-functional thought. The features of romantic language are highlighted especially in the way the composer exploits the color of the tonalities, the chromatic and enormous modulations, the tonal leaps, the harmonies and the cadences, the morphology and the phrasing, all contributing to the integration of a composer-style atmosphere, an osmosis between the poetic and the music in a balance that marks majesty in exploiting the tonal-romantic discourse. The characteristics of the song are based on the thought of harmonizing the first stage of the tone, as it is found in the parts Ca pre imparatul tuturor and Fie numele Domnului binecuvântat of the Liturghia Sfântului Ioan Gură de Aur. Melodic dictonism blends with chromaticism in most of the Romantic work. This can be seen in the Primăvara madrigal on the verses of Vasile Alecsandri. The chromathic melodic notes appear in the madrigal Ziua ninge on the poems of poetry Iarna by Vasile Alecsandri as a consequence of the "step by step" inflections characteristic of the romantic language. The harmonic language of the composer is inextricably linked with the broad, romantic tone of thought. The

* PhD, Lecturer, Faculty of Orthodox Theology at "1 Decembrie 1918" University, Alba Iulia, Romania. 
chromatic melodic notes transform the accords by inducing the idea of continuous tonal inflection. The color of the tonalities, the inflections and the modulations are characteristic of Dima's creation and the tonalities are closely related to the chosen theme material. Generally Gheorghe Dima uses major tones in his madrigals, either as basic tones or by alternating within the same piece the major and the minor to create the express contrast required by the poetic text.

Keywords: romanticism, choral creation, romantic language, madrigal, diatonism, chromatism, color of tonalities, inflections, modulations, romanian composer, Romanian choral music.

An outstanding composer of his time, Gheorghe Dima was born on September 28, 1847 in Brasov, as a son of a family of well-traded merchants who, through the nature of the preoccupations, overlooked Gheorghe's musical talent, considering that unsure artist career. So the young man is sent to Vienna to study at a technical school, and then to Germany in Karlsruhe, where he is in the Politehnica. In this period he discovers the true vocation that directs him towards music.

Endowed with a remarkable bass voice, Gheorghe Dima studies with Heinrich Giehna in Karlsruhe and continues in Vienna with Otto Uffmann. The genesis of these studies was seen on the posters of Klagenfurt, Zürich and Vienna, which featured the name of Gheorghe Dima, who played among others the role of Marcel in the "Hughenotii" by Giacomo Meyerbeer and Bertran in "Robert the Devil" by the same composer.

Willingness to train and compose had led him to join the Conservatoire in Gratz where he studied counterpoint and harmony with Ferdinand Thieriot.

In 1881, Gheorghe Dima returns to his homeland and dedicates all his energy to the ideal of lifting the Romanian musical movement. 
The value of Gheorghe Dima's creation stems primarily from the originality of harmonious dressing, but also from the artistic form of the piano accompaniment, which amplifies the expressiveness of the melodic line. Many of his works were made on the lyrics of the great national poets such as Mihai Eminescu, Vasile Alecsandri, George Coşbuc.

The harmonic universe of the compositional creation of Gheorghe Dima is evidenced by a specific romantic language, which expresses a continuous, passionate tension. Harmony involves a multitude of sound plans, the author's attention being especially directed towards the piano score. The modal nature of harmony can be identified especially in songs inspired by folklore, from "folk songs" (Mugur, mugurel; Mădărulita de demult etc.) and "old Romanian songs" influenced by urban folklore (O inima intristată, Scumpă, dragă copiliță, Rămâi sănătoasă etc.). In all these works one can notice the composer's talent to integrate the major-minor folk melo into the most appropriate harmonic-tonal environment. The vocal and instrumental music, in the creation of songs by Gheorghe Dima, constitute, through the perfection of their unity, the essence and the balance of the represented gender. These two components create a dialogue of melodic lines, contributing to the elaboration of a certain sound atmosphere, to the construction of dynamic and tensional gradations conforming to the compositional intention. Gheorghe Dima's compositions legitimate him as the creator of Romanian romantic lied and the status of a brilliant precursor of the Romanian national music school.

In the essential data of choral and vocal creation, Gheorghe.Dima retains all the attributes of the romantic language in which it was formed. These attributes are revealed especially in his religious choirs and in the madrigals where the melodic invention, the harmonic conception, the inflections and the modulations betray an eminently tonal-functional thinking. The 
features of romantic language are particularly evident in the way the composer exploits the color of tonalities, chromatic and enormous modulations, tonal leaps, harmonies and cadences, morphology and phrasing, all contributing to the completion of a composer-style atmosphere, an osmosis between the poetic image and the musicals that are in a balance of mastery in the exploitation of the tonal-romantic discourse.

The characteristics of the romantic inspiration are based on that tone of tone that includes the tonality pillars of the agreement of the first stage of the tone, as we can see in Liturghia Sfântului Ioan Gură de Aur in the parts Carii pre heruvimi A minor, or the parts $C a$ pre impăratul tuturor, Fie Numele Domnului Binecuvântat A major.

Ex. Liturghia Sfântului Ioan Gură de Aur, Ca pre împăratul:

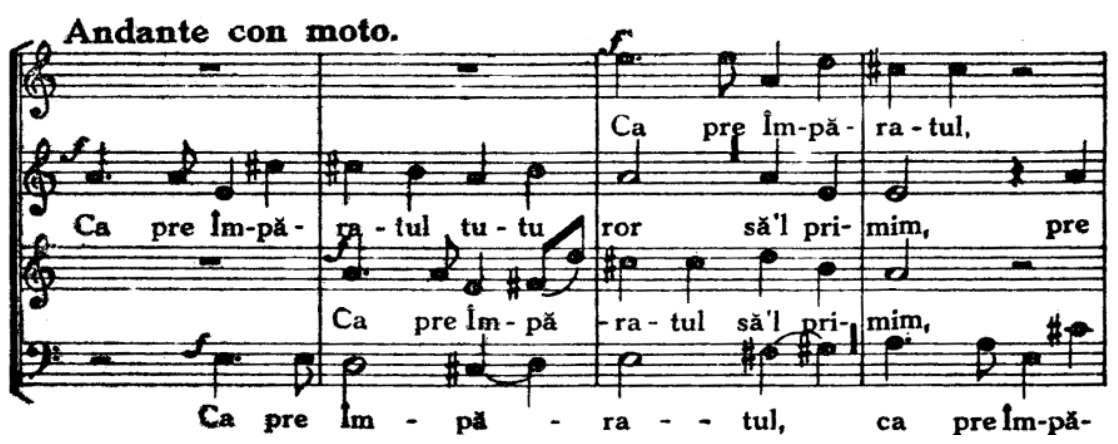

Melodic diatonism intertwines with chromaticism as a melodic color element. This is evident in most works where romantic inspiration. This can also be observed in the melody of the madrigal Primăvara on the lyrics of Vasile Alecsandri, folkloric inspiration, in which the composer transposes the popular ethos by resorting to the A major to A minor, minor-tomajor tonal play. It is the pedal on the face that imitates the popular ison, first-time functions of the second measure (1st and 5th stages with the seventh), the fourth-degree plausible chaining, 
the chromatic passage notes in the bass and the other, the unison with the inferior alteration of the agreement's quintet the first and unusual cadence on the 7 th stage, all of which are part of the "arsenal" of means of expression that distinguishes the composer's style.

Ex. Primăvara:

Tranquillo e dolce M.M. $126=\Omega$
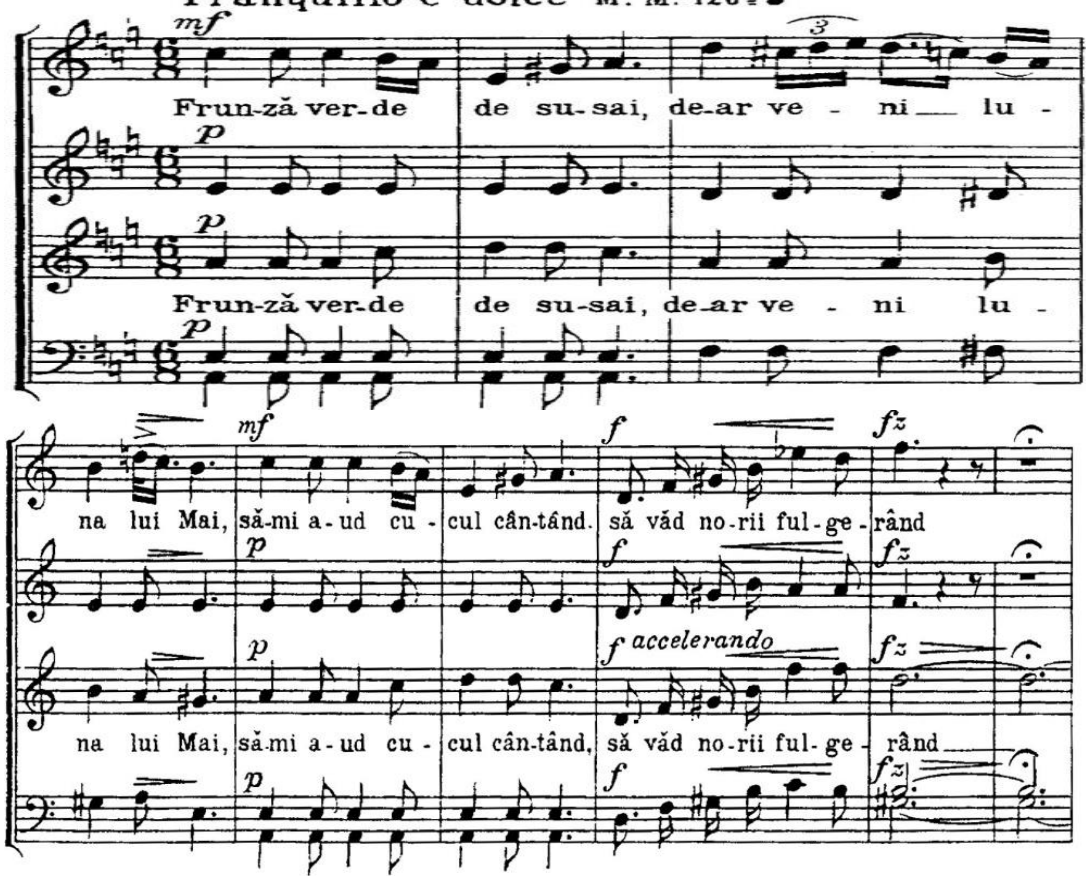

The chromathic melodics notes appear as a consequence of the "step-by-step" inflections characteristic of romantic language. We observe the same arpegiatar profile of the song, this time sequenced, as well as the ladder of the scale, in the madrigal Ziua ninge on the verses of the poetry by V. Alecsandri. Also, in the second sentence, the bass chromatic walking is a delay for the function of the base but, from the third, the apogiatura faints and 
the sensitivity of the ground in the melodic walking. The sib passage note is meant to induce inflection at the major $\mathrm{Fa}$.

Ex. Ziua ninge:

chromatic apogiatry

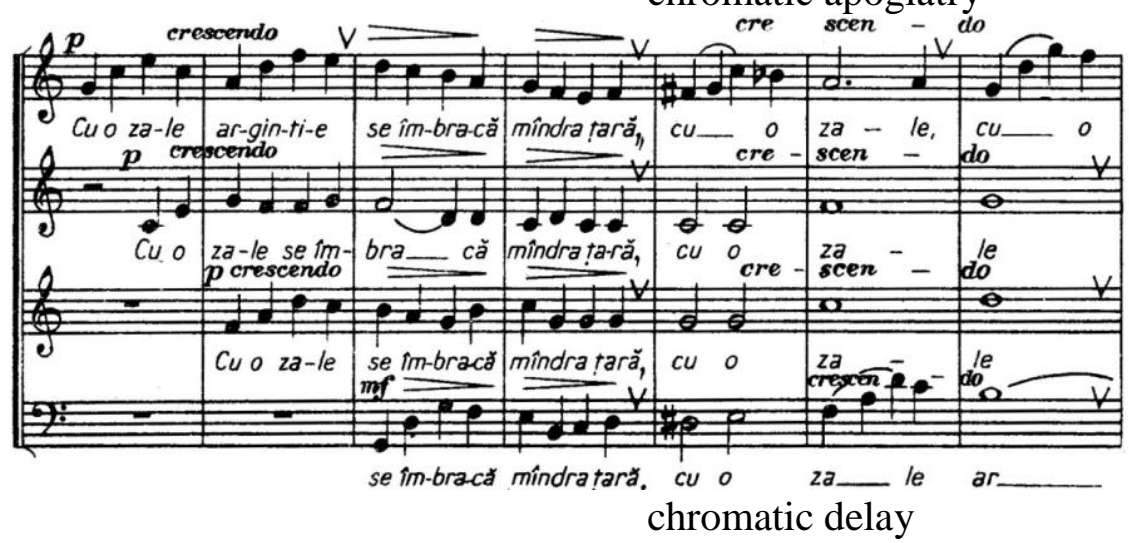

In the choir Două inimi nu-mi dau pace, the composer uses altered exchange notes resulting from third-party mixes of the upper voices, on a pedal of the basal ground function of bases and tenors.

Ex. Două inimi nu-mi dau pace (exchange notes chromatic):

Un poco più lento

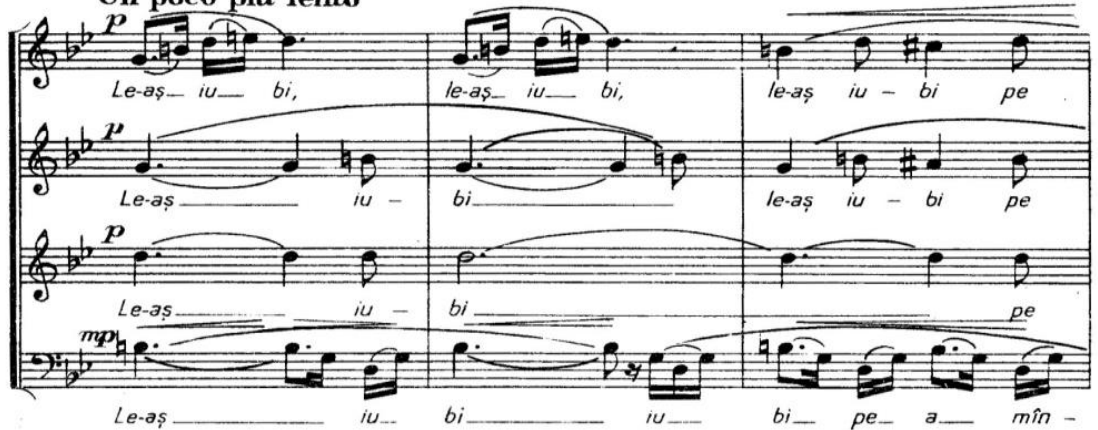

The fact that "Tonality can only be thought of harmoniously" is a phenomenon that prof. Dr. Constantin Ripa 
theorizes in the Superior Theory of Music $^{1}$, posturing the principle according to which the harmonic vertical thinking organizes the tonal-functional musical discourse. We see how this principle is reflected in Gheorghe Dima's creation both the songs quoted (such as folk songs) and in the songs created by the composer and how "... By enfolding the harmonic tensions, the functional baroque-classical-romantic melody acquires a certain pregnancy that detaches her from the previous modal melody, becoming the main carrier of expressive content. ${ }^{2 "}$

In the case of the chorus melody Două inimi nu-mi dau pace, the chromatic step of the melody is due to the remodeling from the $\mathrm{Bb}$ major to $\mathrm{G}$ minor mass tone by introducing the sensitive $\mathrm{F} \#$ into the agreement of the dominant tonality function.

Ex. Două inimi nu-mi dau pace:

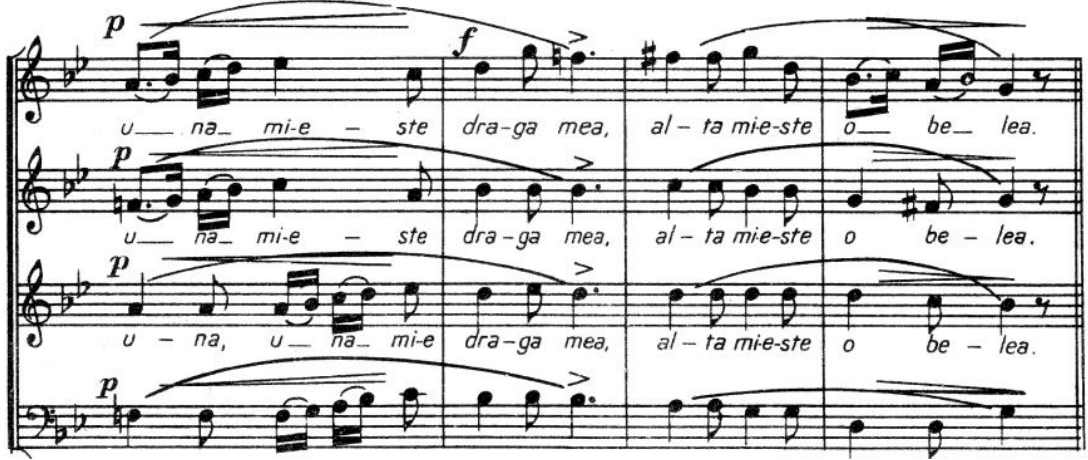

The harmonic language of the composer is inextricably linked with thinking through extended, romantic tone. The phenomenon is also known, theorized, and refers to "continuous, floating modulation, always evolving towards a new tonic, which, like a" morgan girl ", is hardly reached and materialized. The

${ }^{1}$ C. RÎPA, Superior Music Theory - Tonal Systems, Ed. Media Musica, 2001, p. 200.

2 Ibidem, p. 214. 
very notion of modulation seems to have changed its definition now, but rather returning to the meaning of inflection. ${ }^{3 "}$

Even though in Gh.Dima's harmonic language we encounter especially the "phase" of a romantic classicism, the modulations or inflexions not so common, there are still fragments in which the principle of "continuous dominance" reflects that deep, romantic tension characteristic of style. It is the case of the final cadence of Carii pre cheruvimi choir, in which on the lyrics of all the worldly care we deny, the composer builds a moment of amazing beauty through the harmonic density. Interpreted in $\mathrm{pp}$ this confers on the auditor that inner peace that the believer desires by liberating from the "earthly" dimension and stepping into a spiritual dimension.

Inflections are as follows: La-Fa \# - fa \# -Si- La:

Ex. Liturghia Sfântului Ioan Gură de Aur, Cari pre cheruvimi:

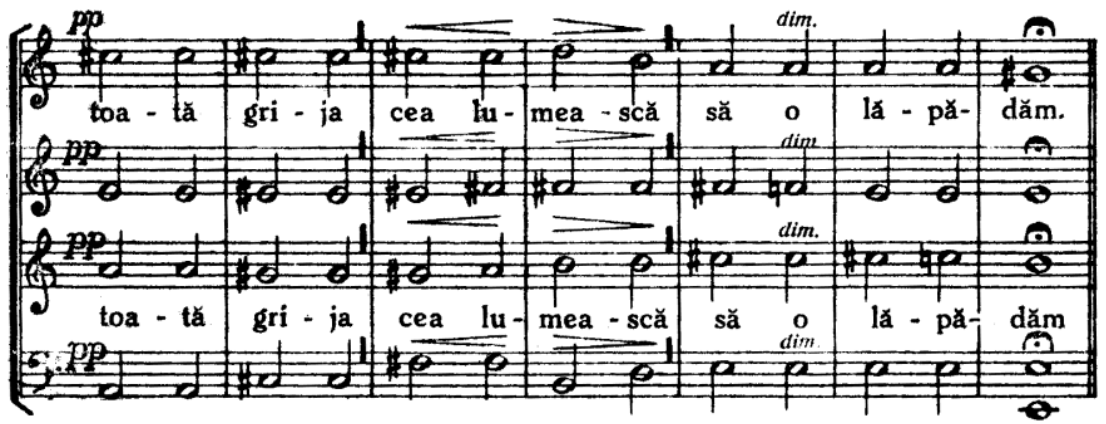

The continuous use of the secondary stages (such as the third stage of the functionally uncertain), the seventh arrangements that allow the delays in all voices but especially in the bass, create a state of continual instability, on sometimes stretched fragments, as we meet on Ziua ninge. The first stroke of the madrigal reflects this tonal "uncertainty", initiating inflections

${ }^{3}$ Ibidem, p. 246. 
through altered achords that do not find the tonic function, and they are in turn dominant functions for the next avoidance tonic. The final cadence is also open to the dominant. The imitative polyphonic scribe but also the harmonic delays "destabilize" the square structure of the phrases, the period being asymmetric, of 11 measures.

Ex. Ziua ninge:

Adagio

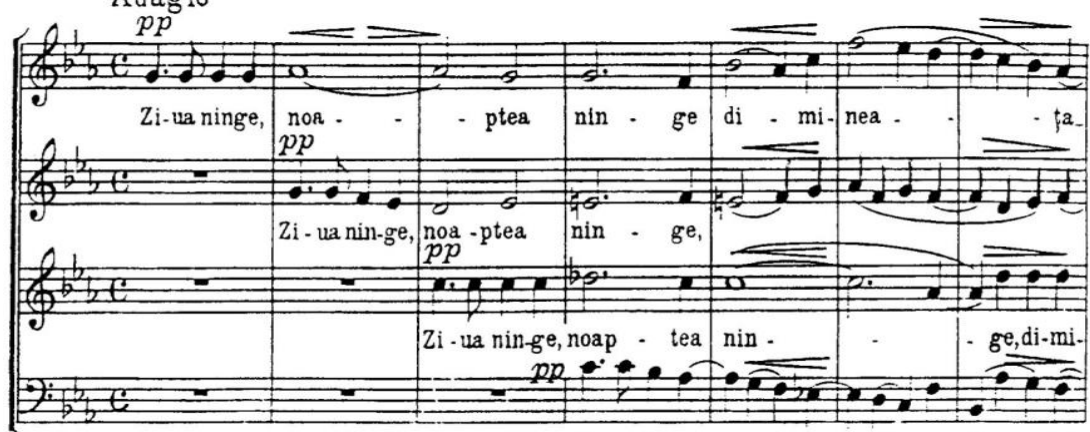

Zi-ua nin-ge noap-tea nin-ge di - mi-

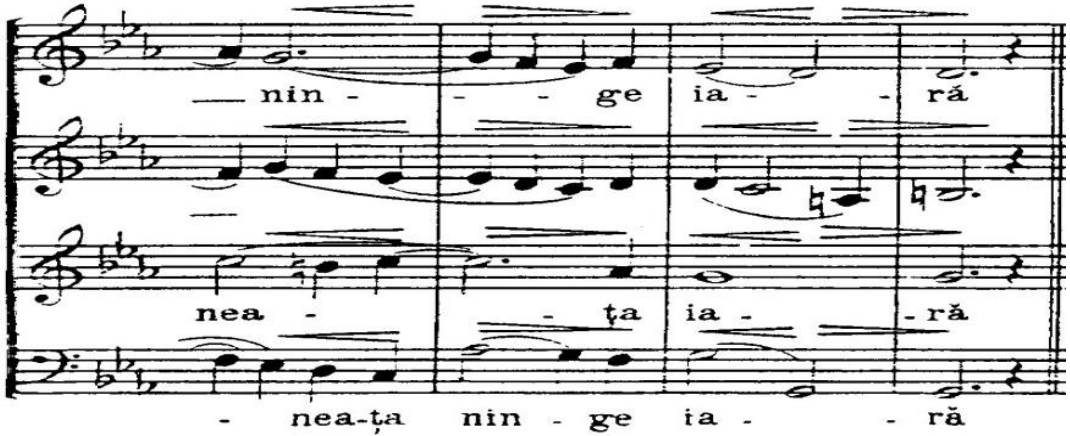

The chromathic melodic notes transform the accords and "color" the basic tone by inducing the idea of continuous tonal inflection. The passage notes in the following fragment, by altered agreements, only "hint" to the major F, G minor, G major soil within the $\mathrm{C}$ major tonality tone. Avoiding the final cadence, the fragment, the fundamental, using the secondary steps and the 
delays, outlines that romantic "unease" it originates from evolved harmonic thinking.

Ex. Ziua ninge:

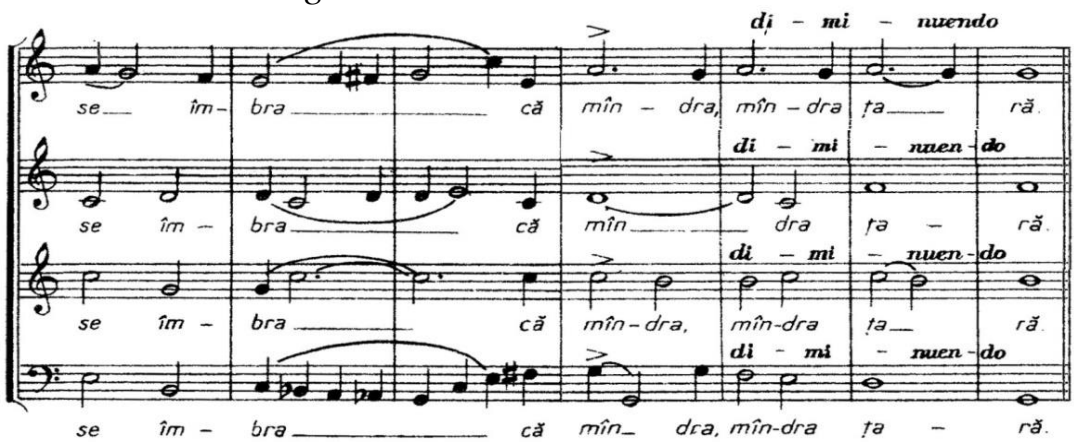

The accumulation of chromatic graces notes with sensitive function creates sometimes altered chords, enarmonics, as we can see in Hora, mixed choir and piano. We observe in the piano double sensation, ascending and descending sequence of the first step agreement ground in the $\mathrm{G}$ major ground, as well as the third, the shrinking agreement generated: $\mathrm{Eb} G \mathrm{~A} \# \mathrm{C}$ \# interpreted enarmonic $\mathrm{Eb} \mathrm{G} \mathrm{Bb} \mathrm{Db}$, being solved on quartsex the first stage.

Ex. Hora:

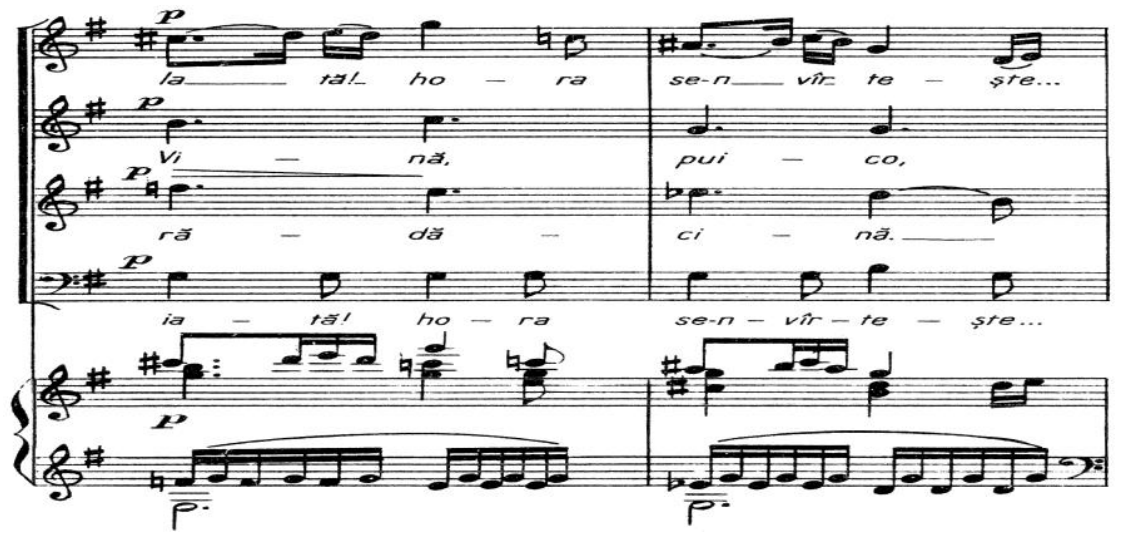

Polemic accord 
The double exchange notes in the inner voices of the musical discourse also have the role of maintaining harmonic tension and creating a break in the rhythm of the main stages.

In the choir of Carii pre heruvimi in the Liturghia Sfantului Ioan Gură de Aur, the final I-V- I cadence in E major to which modulation tends is tensioned by an altered agreement. Thus, a possible interpretation of the agreement is created by altering the function of the second step in E major: F- the fundamental ascended, A\# ascended step, $\mathrm{C}$ to the lower half, and to $\mathrm{E}$ the seventh:

Ex: Liturghia Sfântului Ioan Gură de Aur, Cari pre cheruvimi:

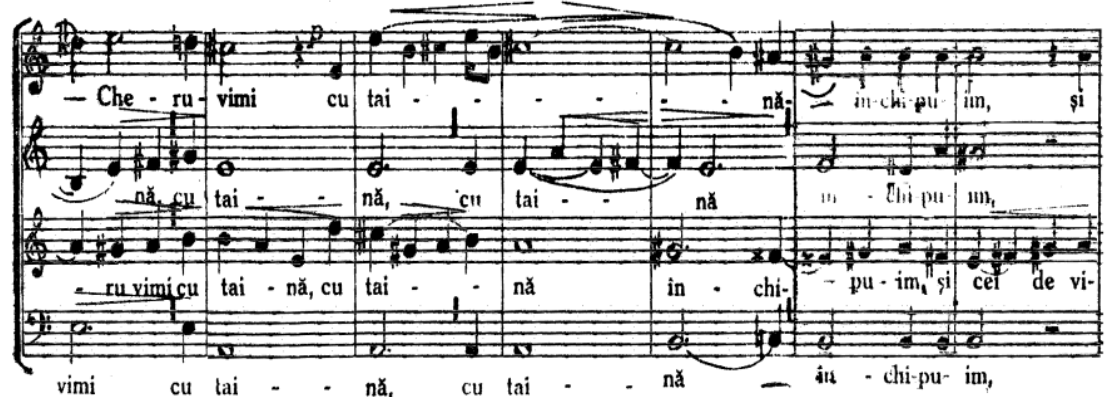

The case is met, and in the Sfânt este Domnul Savaoth measure 5-6. The interpretation of these agreements we believe should be made through the melodic leadership of the internal voices of the harmonic discourse due to the fact that Gheorghe Dima presents an eminently polyphonic thought in this Liturgy by an unimaginable romantic expressive force.

Gheorghe Dima's romantic creation is characterized by a great variety of means of exploiting the expressive resources of the used tones. A first finding would be that the tone is closely related to the chosen material. Gheorghe Dima generally uses major tonalities in his madrigals: either as basic tonalities (Primăvara -A major), or alternating within the same piece, 
major and minor to create the express contrast required by the poetic text (Ziua ninge-C minor- $\mathrm{C}$ major). As for the works in which the popular quote appears, or even the melodic invention with folk inspiration, the composer is attracted to the minor tones. It is the case of choirs: Cucuruz cu frunza-n sus, G minor, Hei, leliță din cel sat $\mathrm{G}$ minor, $\mathrm{Nu}$ m-arde dorul, - A minor, Anika de la moară- A minor, Carausul - B minor, Două inimi nu-mi dau pace - popular inspiration, $\mathrm{G}$ minor.

Modulations and inflections are primarily related to first degree related tones, modulation to relative (Cucuruz cu frunza-n sus, Gmin.- Bb, Primăvara, Amaj.-Amin. -F\#min. -Emaj.)

An outstanding representative of Romanian music, Gheorghe Dima was the creator who understood and interpreted musically the aspirations and pains of our people, who made a tireless activity for the flourishing of Romanian art, an example of work for true art, for which the Academy of Music in ClujNapoca bears his name. The Philharmonic in Brasov also bears its name since 1946 .

\section{References}

1. Anghel, Irinel, Directions, Current Romanian Music in the Second Half of the 20th Century, Muzical Publishing House, Bucharest, 1997.

2. Cosma, Lazăr-Octavian, Hronicul muzicii româneşti, vol VII, Musical Publishing House, Bucharest, 1986.

3. Cosma, Viorel, Romanian Musicians, Lexicon, Musical Publishing House, Bucharest, 1970.

4. IDEM, Musicians in Romania, Vol. III, F-G, Musical Publishing House, Bucharest, 2000.

5. EISIKOVITS, Max, Introduction to Voice Polyphony of the 20th Century, Musical Publishing House, Bucharest, 1976.

6. FIRCA, Gheorghe, Structures and Functions in the Modal Harmony, Musical Publishing House, Bucharest, 1988. 
7. HeRman, Vasile, Modal Aspects in Contemporary Romanian Creation, in Musical Studies, vol. III, Bucharest, 1967.

8. IDEM, Form and Style in the New Romanian Music Creation, Music Publishing House, Bucharest, 1977.

9. POPOVICI, Doru, Romanian Choir Music, Music Publishing House, Bucharest, 1966.

10. RîPĂ, Constantin, Superior Music Theory, Vol I, Tonal Systems, Media Musica Publishing House, Cluj-Napoca, 2001.

11. IDEM, The Superior Theory of Music, vol. II, The Rhythm, MediaMusica Publishing House, Cluj-Napoca, 2002.

12. TERENYI, Ede, Harmony of Modern Music, 1900-1950, „Gheorghe Dima” Music Conservatory, Cluj Napoca, 1983.

13. TIMARU, Valentin, Course of Musical Forms and Analysis II, Academy of Music Gh Dima, Cluj-Napoca, 1984.

14. Voiculescu, Dan, Polyphony of the 20th Century, Musical Publishing House, Bucharest, 2005. 